\title{
Effect of Nutritional Intervention on some Metabolic Syndrome Risk Factors among Adults
}

\section{Ekbal Mahmoud Mohamed, ${ }^{1}$ El Sayed Mah. Hammad, ${ }^{2}$ Safaa T. Gohari $^{1}$ and Manar Mostafa Abd Elrhman ${ }^{2}$}

1- Nutrition \& food science, Home Economic Dept. Fuculty of Specific Education, Ain Shams University.

2- Clinical Nutrition Department. National Nutrition Institute - Cairo.

\section{ABSTRACT}

$\lambda \begin{aligned} & \text { etabolic syndrome }(M S) \text { is characterized by a combination of metabolic } \\ & \text { risk factors such as abdominal obesity, raised triglycerides, lowered } \\ & \text { high-density lipoprotein cholesterol }(H D L-c) \text {, hypertension and impaired }\end{aligned}$ glucose tolerance. This study was carried out estimate the effect of dietary lifestyle intervention on some risk factors of metabolic syndrome among selected adult cases. The study was conducted on 140 adults, (20-60 years), males and females suffering from one or more of MS risk factors. Dietary and lifestyle intervention ( 3 months of adequate diet, healthy lifestyle and nutritional education) for 50 cases selected with high risk factors. Anthropometric, laboratory and dietary assessments were made at baseline and at the end of intervention. Results of dietary and lifestyle intervention showed very high significant changes $(p<0.0001)$ especially for anthropometric measurements of cases $(n=50)$, weight and BMI were decreased by about $13.7 \%$, waist circumferences, and hip circumferences were reduced by $13 \%$, and $9 \%$ respectively by the end point of the intervention period. These changes also lead to laboratory improvement in syndrome indicators like FBG (fasting blood glucose), lipid profiles (TC (total cholesterol), TG (triglyceride), LDL-c (lowdensity lipoprotein cholesterol), and HDL-c). Conclusion: Diet and lifestyle modifications are the first line of treatment in dealing with MS. Decreasing about $10 \%$ of body weight is very useful for preventing or reducing metabolic syndrome risk factors and its complications among adults. Recommendation: balanced caloric intake and physical activity to achieve and maintain a healthy body weight as possible are essential.

Key words: Metabolic syndrome - riskfactors - adults - Dietary intervention 
INTRODUCTION

\section{Metabolic}

syndrome

(MS) is a growing cause of morbidity and mortality worldwide and is characterized by the presence of a variety of metabolic disturbances. Although the risk for MS has significantly attributed to adult lifestyle factors such as a person who takes many calories of much saturated fat, and neither gets enough physical activity nor good nutrition, and smoking. MS propagation is rapidly increasing with rising obesity and sedentary lifestyles worldwide especially in low- and middle-income countries (Walker et al., 2012).

Prevention, early screening and early intervention of the MS are recognized to be important in decreasing the morbidity and mortality associated with cardiovascular diseases (CVD), diabetes and their complications (Ahmed et al., 2014). Due to the limited number of studies or due to variations in definitions /classifications of risk factors between studies a meta-analysis and quantification of the strength of association could not be performed. Generally, the individual disorders that compose the MS are treated separately (Van Namen et al., 2019).

The most effective intervention for MS treatment is the caloric restriction that supports 7-10\% weight loss as an appropriate goal for people with MS risk factors, unless additional weight loss is desired for other purposes. There is no perfect combination of macronutrients useful for all individuals. Adaptations of dietary recommendations based on socioeconomic factors, food availability, and personal preferences are very important (Van Namen et al., 2019).

The main concern about MS is the prevention of diabetes and the associated cardiovascular risk development and achieving weight loss (Evert et al., 2019).

The prevalence of MS in the adult population worldwide varies from 8 to $24.4 \%$ in males and from 7 to $46.5 \%$ in females (Ahmed et al., 2014). The prevalence of MS in the adult population worldwide estimated that $\sim 20-25 \%$ of the world's adult population have MS (IDf, 2016). The prevalence of MS in Egypt is $55 \%$ among the whole sample, $85.6 \%$ among diabetics and $76.6 \%$

Bulletin of the National Nutrition Institute of the Arab Republic of Egypt. December 2019 (54)97 
among hypertensive patients (Khaled et al., 2014). In Egypt, another recent study (Maklady $\boldsymbol{e t}$ al., 2014) done on a sample of 145 inhabitants of the Suez Canal area reported a prevalence rate of MS among adults of $42.1 \%$. Although they reported a lower prevalence rate of MS yet, $11.1 \%$ of subjects had all five criteria of MS, which was so exceeded their study. The prevalence of MS among obese Egyptian college students was (24.37\%) (Ahmed et al., 2014).

This research aimed to estimate the relation between metabolic syndrome risk factors and dietary pattern and to estimate the effect of dietary intervention on some risk factors of metabolic syndrome among selected adult cases.

\section{SUBJECTS \& METHODS}

This study was conducted on 140 adults aged 20 to 60 years through two phases: first phase: Screening for risk factors of metabolic syndrome among (140) adult cases selected from various outpatient clinics. Second phase: Dietary intervention (Suitable tailored diet, healthy life style and nutritional education) for 50 cases that were selected with high risk factors.

\section{Subjects exposed to:}

1- Routine Medical examination including full history, family history of related chronic diseases; blood pressure was also measured (Owusu et al, 2015).

2- Anthropometric assessment: (height, weight, BMI, waist and hip circumferences).

3- Dietary assessment as well as 24 hour recall, diet history and food frequency questionnaire. Twenty-four hrs. recall was repeated with selected cases every month and at the end of intervention. The intake of energy and nutrients was computed through the compiled food composition tables of the (NNI, 2006). Adequacy of the diet consumed was assessed by comparing the energy and nutrients intake of the individual with his recommended dietary allowances "RDA" using (FAO and WHO, 2004) recommendations. 
4- Laboratory assessment: Serum lipid profiles $(\mathrm{TCH}$, TG, HDL-c, LDL-c) were determined according to the method described by Allain et al., (1974), Trinder and Ann (1969), Lopes - Virella et al., (1977), respectively. Serum LDL were calculated according to Friedwald et al., (1972). Fasting blood glucose determined by Young et al., (1972), Liver function (ALT, AST) estimated by Reitman and Frankel (1957), Kidney function, Creatinine was determined according to the method described by Faulkner and King (1976). Hemoglobin evaluated according to (Bain et al., 2012).

5- Physical activity also registered as regards the duration and frequency of physical activity and duration of lying down were categorized.

\section{Exclusion Criteria:}

- Pregnant or lactating women.
- Who already an unusual restrictive diet

- Subjects with a major illness such as cancer, hepatic or cardiac diseases.

- The inability for physical activity.

\section{Nutrition education program:}

The program consisted of two modules that were delivered to the participants at six sessions individually and group discussion. Module (1) - Basic nutrition, (four sessions, one hour for each session). At the end of these sessions, the participants should be aware of:

* The food guide pyramid and healthy plate.

- Food groups like grains, fruits, vegetables, milk, meat \& meat substitutes, fat \& sugars and lastly fluids.

The food items and theirs serving size in each group.

Module (2) - Metabolic syndrome (two sessions, one hour for each session). At the end of these sessions, the participants should be able to: 
* Define MS and recognize its related risk factors.

- Identify the importance of the promotion of a healthy lifestyle (diet and exercise) in the treatment and prevention of MS.

\section{Healthy lifestyle intervention:}

An intervention program on diet/lifestyle modifications was implemented for 3 months period on a subsample of the high-risk group $(n=50)$. This group received individualized dietary education including the recommended daily caloric intake, balanced diet, food exchanges and food guide pyramid. The daily caloric requirement was calculated according to body weight, height, sex, age and activity level of each case in the first visit and every follow up visit according to (IOM, 2005). Restriction intake of total and saturated fat to be less than $30 \%$ and $10 \%$ from total energy consumption respectively were recommended. Low fat milk and meat products were also recommended. All fast foods, soft drinks and junk foods were encouraged to be substituted by healthy foods like whole-grain products and fiber rich vegetables and fruits. All cases were advised to restrict their sedentary lifestyles (i.e., watching television) to less than 1 hour per day and continued everyday home exercise at least 30 minutes per day.

\section{Consent Form}

All cases were explained in details about the study and investigation that will be done and signed the informed consent for the study. Their agreements were taken orally. Who agree shared with us.

\section{Statistical Analysis}

Data were analyzed by SPSS statistical package version 21 . The results were reported as a percentage and mean $\pm \mathrm{SD}$. The results were evaluated by using Compare means (paired- samples $\mathrm{t}$ test). Statistical significant considered at $\mathrm{P}<0.05$ (Snedecor and Cochran, 1967).

\section{RESULTS \& DISCUSSION}

The main results of this study as shown in table (1) showed that the average studied sample age was $(\mathbf{3 9 . 3 6} \pm \mathbf{1 8 . 4 6})$ years and average of their weight was $(92.94 \pm 16.000) \mathrm{kg}$. The 
average of BMI was (33.59 \pm 8.178) $\mathrm{kg} / \mathrm{m}^{2}$. Results illustrated that most of the studied sample was obese and had central obesity. Results of waist circumferences and waist to hip ratio which illustrated the presence of central obesity were in matching with (StOnge, 2005) who stated that percent body fat increases, lean mass and bone mineral density decrease in general as individuals age. Furthermore, the increase in fat mass is distributed more specifically in the abdominal region. It has been well documented that as individuals age, body composition changes, even in the absence of changes in body weight. In addition, other studies have shown that fat mass increases and muscle mass decreases with age Atlantis $\boldsymbol{e t}$ al., (2008).

Results of table (2) showed that the means of systolic and diastolic blood pressure were $(136.33 \pm 14.92)$ and $(89.60 \pm 9.55)$ $\mathrm{mm} \mathrm{Hg}$ respectively. Regarding to laboratory findings, results of this table showed that mean of fasting blood glucose was 103.721$\mathbf{\mathbf { 2 9 . 6 9 }} \mathrm{mg} / \mathrm{dl}$ and cholesterol was $184.857- \pm 30.931 \mathrm{mg} / \mathrm{dl}$ while LDL-c was $111.340- \pm 23.981$ $\mathrm{mg} / \mathrm{dl}$ at the opposite of $\mathrm{HDL}$, which was $41.764- \pm 6.138 \mathrm{mg} / \mathrm{dl}$, and T.G was 135.15- \pm 56.44 $\mathrm{mg} / \mathrm{dl}$. Results of table (3) showed that great number of studied sample had risk factors for MS. As more than half $(55 \%)$ of them had high fasting blood sugar $>100$ $\mathrm{mg} / \mathrm{dl}$; near to two-thirds of them $(60.7 \%)$ had high blood pressure > $130 / 85 \mathrm{~mm} \mathrm{Hg}$, near to one third of them (33.6\%) had high blood triglyceride > $150 \mathrm{mg} / \mathrm{dl}$, and around $(37.9 \%)$ of them had Low HDL $<40 \mathrm{mg} / \mathrm{dl}$. Results go in harmony with (Magdy et al., 2014) who showed that there was an increase in serum TG (33\%). Levels of TG are inversely associated with HDL-c and characteristic dyslipidemia with elevated TG and reduced HDL-c levels is regarded as a cardinal sign of insulin resistance. Decreased HDL-c among adults has been associated with factors such as obesity, carbohydrate and fat intake in the diet and decreased physical activity. Results of table (3) matched also with Mattsson $\boldsymbol{e t}$ al., (2007) who reported that an increase in two factors, serum TG and obesity, accounted for much of the increased prevalence of the MS during young adulthood. Our

Bulletin of the National Nutrition Institute of the Arab Republic of Egypt. December 2019 (54)101 
study results also agree with James Osei-Yeboah, (2017) who reported that there is an increase in serum TG (33\%) with comorbidity of diabetes with hypertension ranged from $62.96 \%$ to $66.67 \%$ using the $\mathrm{WHO}$ and the IDF/NCEPATP III, respectively. In addition, this study agrees with Mahrous et al., (2018) who showed that most prevalent MS components high TG levels (40.2\%) and reduced HDL-c levels $(36.3 \%)$. The study results also agreed with those of Puepet et al., (2009); Unadike et al., (2009); Nsiah et al., (2015) and James, (2017) who reported that the most predominant component of MS abnormality among population was high blood pressure using the NCEP-ATP III (66.67\%) and the WHO (62.96) criteria. A study by Faramawi $\boldsymbol{e t}$ al., (2014) conducted in the USA showed that MS and its components, particularly hypertension, increased waist circumference and hyperglycemia, were significantly associated with systolic blood pressure variability. The study results also agree with those of Obeidat et al., (2015) who found that hypertriglyceridemia was the second most prevalent criterion, with a frequency of $40.2 \%$. However, this result was higher than that of Ahmed et al., (2014) who found that elevated TG was $28.4 \%$ in their study. Other metabolic abnormalities include also low HDL-c levels, which were prevalent in $36.3 \%$ of the studied population. This result was in agreement with Sabir et al., (2016) who found that the prevalence of low HDL-c levels was $41.4 \%$. This study dis agreed with (Al Dhaheri et al., 2016) who found that the prevalence of impaired fasting glucose among their study population was $9.7 \%$. Also the results seems higher than a study in Egypt by WHO in 2012 which reported $31.3 \%$ rate of obesity ( $\geq 30 \mathrm{BMI}$ ), 39.7\% rate of hypertension (SBP140 and or DBP 90), $17.2 \%$ rate of raised fasting glycemia and $36.8 \%$ rate of raised total cholesterol.

Main results of this study showed high significant relation between metabolic syndrome risk factors and dietary pattern of the studied sample. Results of table (4) showed dietary intake adequacy from total energy intake, total protein intake, total fat intake, dietary fiber intake and 
dietary intake from selected minerals, as there were more than half of both males and females $(54.5 \%) \quad(56.1 \%) \quad$ respectively were took over energy consumption (>120\% from RDA) with significant differences (0.041) between males and females, and near to two-thirds of males and females $(63.6 \%)$ $(64.5 \%)$ respectively took over Carbohydrate consumption (>120 $\%$ from RDA), on the other hand around half of males and females $(48.5 \%)(58.9 \%)$ respectively took over consumption from protein. Also tables showed that around half of males and females $(54.5 \%), \quad(42.1 \%)$ respectively took over fat consumption. On the other hand only (6\%) (12.1\%) from males and females respectively took over fiber consumption (>120\% from RDA) but around three quarters (75.8\%), (72\%) from males and females respectively took lower fiber consumption ( $<75 \%$ from RDA). Regarding to some selected micronutrients intake, around (41.4\%) of studied sample took acceptable and adequate intake from iron but around one quarter (25\%) of them took lower intake from iron ( $<75 \%$ from RDA) and one third of them $(33.3 \%)$ took over iron consumption (>120\% from RDA) with statistical significant differences (0.063) between males and females. This table also showed that most of studied sample $(81.4 \%)$ and (71.4\%) took lower $\mathrm{Ca}$ and $\mathrm{K}$ consumption (<75\% from RDA) respectively while only $(10 \%)$ of them took normal $\mathrm{Ca}$ consumption (> $75-120 \%$ from RDA) and around one quarter $(25 \%)$ of them took normal intake from $\mathrm{K}$. On the other hand more than half $(55 \%)$ of the studied sample took over $\mathrm{Na}$ consumption (>120\% from RDA) but only around one quarter (25\%) of them took lower $\mathrm{Na}$ consumption.

Dietary life style intervention with a high risk group $(\mathrm{n}=50)$ showed very high significant changes between pre and post intervention for anthropometric measurements at all age categories and sex groups $(\mathrm{p}<0.000)$. Results of table (5) showed that weight was decreased about $13.7 \%$ with the same decreasing in BMI because of not changing in their heights before and after intervention. Waist circumferences were decreased about $13 \%$ and hip circumferences 
were decreased about $9 \%$ by the end of the intervention period. These changes also lead to laboratory improvement in syndrome indicators like fasting blood glucose levels, lipid profile (TC and TG), lipoprotein patterns (LDL-c and HDL-c), among selected cases.

In the present study, most of selected cases already knew their problem of obesity and already need to solve it. This may make them more co-operative and interested of follow up the guidelines of the intervention and may lead to the good results of the intervention. For inactive cases, a progressive increasing in activity to achieve eventually the target was recommended. It was appropriate to start gradually with smaller amounts of physical activity and gradually increasing duration, frequency and intensity over time. It should also be noted that adults who are currently doing low physical activity or doing amounts below the recommended levels achieved more benefits than doing none at all. Study of Tompkins et al., (2011) provide support for future interventions to shift the focus from reducing obesity to increasing physical activity for the prevention of T2DM and weight loss in obese youth may reduce the incidence of T2DM. Moreover, in this study, females had significantly higher rate of MS criteria in contradiction with the conclusions of Morrell $\boldsymbol{e t}$ al., (2012). Comparison between males and females revealed higher rate of central obesity in females as compared to males. Our findings go in harmony with results which reported by the study of Ruano Nieto et al.,(2015) where increased waist circumferences was more frequently reported in females.

This study agrees with Kengne et al., (2012) who reported that the leading component of MS among the females with diabetes was abdominal/central obesity and recorded significantly higher measurements of obesity and adiposity among the females with MS compared to their male counterparts. Also Evert et al., (2019) agrees with this study as he reported that the most effective intervention for MS is caloric restriction. Dietary intervention support a weight loss is an appropriate goal for people with 
prediabetes. There is no perfect combination of macronutrients useful for all individuals. Compliance with a healthier lifestyle and dietary intake are more important than a particular dietary pattern. This represents an advantage for patients confronting MS. Individuals can advance with any healthy plan that is easy for them to follow. It also opens the door to adaptations of dietary recommendations based on socioeconomic factors, food availability, and personal preferences. The main concern with regard to MS is the development of diabetes and the associated cardiovascular risk. Patients with MS have a similar benefit to overweight/obese patients with diabetes from the adoption of several dietary patterns. As already stated, the goal in both conditions is achieving weight loss.

Results also showed high significantly differences between dietary adequacy from total energy intake, macronutrients and dietary fiber intake for the subsample studied pre and post intervention compared to their RDA as shown in table (6). Results showed that near to two-thirds of males and females $\quad(62.5 \%)$

(61.9\%) respectively took over energy pre intervention while only $(12.5 \%)$ (7.1\% )from males and females respectively took over energy consumption post intervention with high significant differences between pre and post intervention, also around 3 quarters of males and females(75\%) (73.8\%) respectively took over carbohydrate pre intervention while only $(12.5 \%) \quad(9.5 \%)$ respectively took over carbohydrate consumption with high significant differences between pre and post intervention. Regarding to protein intake results showed slight changes between pre and post intervention, as around (37.5\%) (47.6\%) from males and females respectively took over protein consumption pre intervention while around (25\%) (31\%) respectively took over protein consumption. Also results showed that the most of males and females $\quad(75 \%) \quad(83.3 \%)$ respectively took over fat consumption pre intervention while only $(25 \%) \quad(7.2 \%)$ respectively took over fat consumption with high significant differences between pre and post 
intervention. Regarding to fiber consumption, results showed that near to two-thirds of males and females $(62.5 \%)$ and $(61.9 \%)$ of males and females respectively took low fiber consumption $(<$ $75 \%$ from their RDA) pre intervention while only $(25 \%)$ $(33.8 \%)$ of males and females respectively took low fiber consumption with high significant differences between pre and post intervention.

Regarding to dietary adequacy of some selected micronutrients for the studied subsample pre and post intervention compared to their RDA. Results of table (7) showed high significantly differences pre and post intervention compared to their RDA. Results of this table showed that around (37.5\%) and $(40.4 \%)$ of males and females respectively took acceptable and adequate intake from iron pre intervention but around one quarter $(25 \%)$ and $(21.4 \%)$ of males and females respectively took higher intake from iron. While around two thirds of males and females (62.5\%) and (59.5\%) respectively took acceptable and adequate intake from iron post intervention and those who took lower iron intake were decreased to $(0 \%)$ and $(7.2 \%)$ of males and females respectively, with statistical significant differences between pre and post intervention. This table also showed that around half of males and females (50\%) and $(52.4 \%)$ respectively took lower $\mathrm{Ca}$ consumption while only (25\% and $28.5 \%$ ) of them took over $\mathrm{Ca}$ consumption and around one quarter $(25 \%)$ and $(19.1 \%)$ of males and females respectively took acceptable and adequate intake from $\mathrm{Ca}$ pre intervention. On the other hand, those who took lower $\mathrm{Ca}$ intake were decreased to around one quarter or less (25\%) and $(19.1 \%)$ of males and females respectively post intervention, and those who took acceptable and adequate $\mathrm{Ca}$ intake were increased to around $(62.5 \%)$ and $(71.4 \%)$ of males and females respectively post intervention. Regarding to $\mathrm{Na}$ consumption, most of males and females $(87.5 \%)$ and $(85.7 \%)$ respectively took over $\mathrm{Na}$ consumption ( $>120 \%$ from RDA) pre intervention while only $(12.5 \%)$ and (11.9) of males and females respectively took over $\mathrm{Na}$ consumption post intervention with high significant differences between pre and post intervention. 
In addition, data of this table showed around (12.5\%) and $(31 \%)$ of males and females respectively took lower $\mathrm{K}$ consumption pre intervention while decreased to $(0 \%)$ of both males and females took lower $\mathrm{K}$ consumption post intervention and most of the studied subsample $(75 \%)$ and $(95.2 \%)$ of males and females respectively took acceptable and adequate $\mathrm{K}$ intake post intervention. These dietary plans agree with those of Irene and Miguel, (2019) who reported that energy intake is made up of carbohydrates and lipids. The accepted range of lipid calories in the diet is very broad and is the opposite of carbohydrates. Therefore, low-lipid or lowcarbohydrate diets contain very different total amounts of lipids. For all adults, the acceptable macronutrient distribution range of total fat is to be $20-35 \%$ of total calorie intake. The amount of fat can influence insulin sensitivity and the risk of developing type 2 diabetes only with intakes greater than 35-40\% of total energy intake. A diet that contains $20-40 \%$ fat does not change insulin sensitivity, regardless of its effect on weight status. Evert et al., (2013) and (the American Diabetic Association) (ADA) recommendded that the sum of carbohydrates and monounsaturated fatty acids should represent $60-70 \%$ of the total energy in the diet. Nevertheless, since the ADA 2014 position statement, there is no "first-line" approach with respect to the optimal carbohydrate quantity in the diet plan, because evidence remains inconclusive. On the other hand, in overweight or obese individuals, low fat diets are equal to but no better than other weight-reducing diets when the goal is weight reduction.

According to laboratory data like fasting blood glucose levels, liver enzymes and kidney function, hemoglobin, and lipid profile (TC, TG, LDL-c, and HDL-c), results showed very high significant differences $(\mathrm{p}=0.00)$ between pre and post intervention. Results of table (8) showed that the mean of fasting blood glucose before intervention was $114.30 \pm 34.25 \mathrm{mg} / \mathrm{dl}$ and post intervention was 103.18 $\pm 22.11 \mathrm{mg} / \mathrm{dl}$. The mean of TG and TC was $150.63 \pm 79.88 \mathrm{mg} / \mathrm{dl}$ and $203.41 \pm 28.86 \quad \mathrm{mg} / \mathrm{dl} \quad \mathrm{pre}$ intervention and was $132.22 \pm$ 
$61.68 \mathrm{mg} / \mathrm{dl}$ and 185.33 $\pm 22.01 \mathrm{mg} / \mathrm{dl}$ post intervention respectively. Mean of LDL-c and HDL-c was $127.16 \pm 26.73 \mathrm{mg} / \mathrm{dl}$ and $40.02 \pm 7.34 \mathrm{mg} / \mathrm{dl}$ pre intervention and was 110.52 $\pm 22.31 \mathrm{mg} / \mathrm{dl}$ and $46.63 \pm 6.43 \mathrm{mg} / \mathrm{dl}$ post intervention for LDL-c and HDL-c respectively. Also results of this table showed slight changes between pre and post intervention laboratory data of both liver enzymes (ALT, AST), kidney function (Creatinine) and hemoglobin.

$$
\text { Results of figure }
$$

showed that more than one quarter of the studied subsample (26\%) had $<3$ risk factors of MS pre intervention while post intervention the percentage increased to more than half of the sample (56\%). Near to 3 quarters (74\%) of the studied subsample had $\geq 3$ risk factors of MS pre intervention but only (44\%) of them had $\geq 3$ risk factors were of MS post intervention. Also data showed not only significant decreasing in those who had 4 risk factors of MS pre and post intervention but also those who had 5 risk factors of MS were disappeared $\quad(0 \%) \quad$ post intervention as shown in table ( 9 ). These results agree with those by Lindstrom and Tuomileho, (2003) and Nawaporn et al., (2010) who demonstrated that lifestyle modification significantly improved metabolic parameters including fasting plasma glucose and cholesterol level of obese subjects. Moreover, found that the lifestyle intervention group maintained greater improvements in weight, fitness, systolic blood pressure and HDL-c levels at the end of intervention period and they indicated that the intensive lifestyle intervention group spent a considerable time at lower CVD risk. These results agreed with Kelishadi et al., (2007) who found that in all age groups, 3 factors or more were loaded in persons with the MS like cholesterol /triglycerides, metabolic factors /adiposity, and blood pressure. However, waist circumference was the only variable that was loaded for all groups. Also the results agree with those of Panagiotakos and Polychronopoulos., (2005) and De Flines and Scheen, (2010) who mentioned that it would be necessary to pay attention to diet, physical activity, obesity, 
components of MS and insulin resistance in MS management. They suggested that lifestyle changes are an adequate method to lead MS components and only in the case that this intervention would be not enough, a pharmacological mediation should be contemplated. In general, it is thought that dietary patterns could play an important role in MS management. In Egypt, a recent study done by Maklady et al., (2014) on a sample of 145 inhabitants of the Suez Canal area found that $11.1 \%$ of subjects had all five criteria of MS which was lower than this study (26\%) of studied subsample.

\section{CONCLUSION}

Diet and lifestyle modifications are the first line of treatment in dealing with metabolic syndrome as the main recommendations are to balance caloric intake and physical activity to achieve and maintain a healthy body weight as possible. This means that the healthy life style intervention (by encouraging daily physical activities, exercises with balanced low caloric diet and planning to reduce about $10 \%$ from body weight) is very useful for preventing or reducing metabolic syndrome risk factors and its complications among adults.

\section{RECOMMENDATIONS}

Lifestyle modifications and individual based recommenddations:

The main recommenddations are to balance caloric intake and physical activity to achieve and maintain a healthy body weight as possible as by decreasing body weight gradually even $10 \%$ only, Increasing physical activities even few walking daily. Having a healthy and balanced diet even outside home. Consume a diet rich in vegetables and fruits; choose whole-grain, high-fiber foods. Consume fish, at least twice a week and limit intake of saturated fat to $<10 \%$ of energy, total fat to $<30 \%$ of energy, and cholesterol to $<300 \mathrm{mg} / \mathrm{d}$ by choosing lean meats and vegetable alternatives. Fat-free (skim) or low-fat dairy products and minimize intake of hydrogenated fats; minimize intake of carbonated beverages and drinks with added sugars; choose and prepare foods with little or no salt ,Setting a suitable 
time for healthy meals, physical activity and limiting screen times.

Governorate-Based Recommendations as:

Providing as possible as protected open areas, sidewalks and open garden zones. Providing health nutritional care programs for effective MS treatment are needed. Widely screening population especially among obese adults is still urgent for detection, diagnosis, and management strategies for metabolic syndrome risk factors.

\section{REFERENCES}

Ahmed MM; Ellithy AM; Hamed MA and Kasem HS (2014):

Prevalence of metabolic syndrome among obese Egyptian college students. Med J Cairo Univ; 82:305-311.

Al Dhaheri AS; Mohamad MN; Jarrar AH; Ohuma EO; Ismail LC; Al Meqbaali FT, and et al (2016):

A cross-sectional study of the prevalence of metabolic syndrome among young female emirati adults. PLoS One; 11:7. 17.

\begin{abstract}
Atlantis E; Martin S; Haren M; Taylor A and Wittert G (2008):

Lifestyle factors associated with age-related differences in body composition: the Florey Adelaide Male Aging Study. Am. J. Clin. Nutr. 88:95-104.
\end{abstract}

\section{Bain BJ; Bates I; Laffan MA and Lewis SM (2012): \\ Dacie and Lewis Practical Haematology, Eleventh Edition, Elsevere.}

\section{De Flines $\mathbf{J}$ and Scheen $\mathrm{AJ}$ (2010):}

Management of metabolic syndrome and associated cardiovascular risk factors. Acta Gastroenterol Belg ; 73(2): 261-6. 
DNPCNCD. (2008):

Diet, nutrition and prevention of chronic noncommunicable diseases among adolescents: Final report of National Survey of National Nutrition Institute, Egypt.

Evert AB; Dennison M; Gardner CD; Garvey WT; Lau KHK; MacLeod J; Mitri J; Pereira RF; Rawlings K; Robinson S and et al (2019):

Nutrition Therapy for Adults with Diabetes or Prediabetes: A Consensus Report. Diabetes Care, 42, 731-754.

Evert AB; Boucher JL; Cypress M; Dunbar SA; Franz MJ; Mayer-Davis EJ; Neumiller JJ; Nwankwo R; Verdi CL; Urbanski $P$ and et al (2013):

Nutrition therapy recommendations for the management of adults with diabetes. Diabetes Care, 36, 3821-3842.

Faramawi MF; Delongchamp R; Said Q and et al (2014):

Metabolic syndrome is associated with visit-to- visit systolic blood pressure variability in the US adults. Hypertens Res;37(9):875 -9.

FAO/WHO (2004):

Food and Agriculture Organization, World Health Organization, Human vitamin and mineral requirements. Report of a joint FAO/WHO, Human Energy requirements. Report of a joint FAO / WHO Expert Consultation. World Health Organization, Geneva.

Faulkner NR and King JW (1976):

"Fundamental of Clinical Chemistry". 2nd Ed. Tietz Editor. Saunders Philadelphia, 994-998

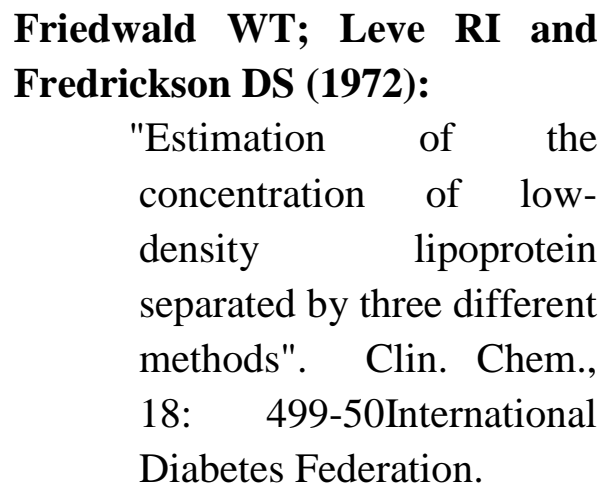

Friedwald WT; Leve RI and "Estimation of the concentration of lowseparated by three different methods". Clin. Chem., Diabetes Federation. 
The IDF (2016):

Consensus worldwide definition of the metabolic syndrome 2006; Available from: http://www.idf.org/ web data /docs /IDF_Meta_def_final. pdf. Accessed 25 Dec 2016.

IOM (Institute of Medicine of the National Academies, Food and Nutrition Board (2005) :

Dietary reference intakes for energy, carbohydrate, fiber, fat, fatty acids, Cholesterol, protein, and amino acids, Washington, DC, The National Academies Press.

Irene Hoyas and Miguel LeonSanz (2019):

Review Nutritional
Challenges in Metabolic
Syndrome Journal of
clinical medicine .J. Clin.
Med Received: 22 July
2019; Accepted: 19 August
2019; Published: 24
August 2019,

Lopes-Virella MF; Stone S; Ellis $S$ and Collwell JA (1977):

"Cholesterol determination in high-density lipoprotein separated by three different methods". Clin. Chem., 23 (5) : 882

James Osei-Yeboah (2017):

(The Prevalence of Metabolic Syndrome and Its Components among People with Type 2 Diabetes in the Ho Municipality, Ghana: A Cross-Sectional Study), International Journal of Chronic Diseases Volume 2017.

Kelishadi R; Ardalan G and Adeli K (2007):

$\begin{aligned} & \text { Factor analysis of } \\ & \text { cardiovascular }\end{aligned}$
clustering in pediatric
metabolic
CASPIAN Study. Ann
Nutr Metab; 51(3): 208-
215 .

Kengne AP; Limen SN; Sobngwi E.; Djouogo CFT and Nouedoui C (2012):

"Metabolic syndrome in type 2 diabetes: comparative prevalence according to two sets of diagnostic 8 International Journal of Chronic 
Diseases criteria in sub-

Saharan Africans,"

Diabetology and

Metabolic Syndrome, vol.

4, article 22.

Khaled, M. Abd Elaziz; Mohamed, S. Gabal; Ola, Abdelsamie Aldafrawy; Hasnaa, Abdel-Al Abou Seif1 and Mohamed Farouk Allam, (2014).

Prevalence of metabolic syndrome and cardiovascular risk factors among voluntary screened middle-aged and elderly, Egyptians Journal of Public Health, 37(4): 612617.

\section{Lindstrom $\mathbf{J}$ and Tuomilehto $\mathbf{J}$} (2003):

The diabetes risk score: a practical tool to predict type 2 diabetes risk. Diabetes Care 26:725-731.

Mahrous OA; Anwar El Shazly HM; Badr SA; Ibraheem RA; Kasemy ZA and El Sheikh GM (2018):

Epidemiology of metabolic syndrome in Menoufia University students.
Menoufia Med J; 31:83945.

Maklady FAH; Kamal HM; ElEraky AZ et al (2014):

Prevalence of metabolic syndrome among adults in Suez Canal area. Egypt Heart J; 66:1 -35.

Mattsson N; Ronnemaa T; Juonala $\mathrm{M}$; Viikari $\mathbf{J}$ and Raitakari OT (2007):

The prevalence of the metabolic syndrome in young adults. The Cardiovascular Risk in Young Finns Study. Intern Med J; 261:159-169.

Morrell JS; Lofgren IE; Burke JD and Reilly RA (2012):

Metabolic syndrome, obesity, and related risk factors among college men and women. $J$ Am Coll Health; 60(1):82-9.

\section{National Nutation Institute (NNI), (2006):}

National Nutation Institute Egyptian food composition tables. 
Nawaporn N; Pairunyar $\mathbf{N}$; Jeerunda S; Pornpimol K; Renu W and Supawadee L (2010):

Successful Strategy to Improve Glucose Tolerance in Thai Obese Youth .J Med Assoc Thai; 93 (Suppl. 6): S131-S138.

\section{Nsiah K; Shang V; Boateng K} and Mensah F (2015):

"Prevalence of metabolic syndrome in type 2 diabetes mellitus patients," International Journal of Applied and Basic Medical Research, vol. 5, no. 2, p. 133.

Obeidat AA; Ahmad MN; Haddad FH and Azzeh FS (2015):

Alarming high prevalence of metabolic syndrome among Jordanian adults. Pak J Med Sci; 31:13771382.

Owusu I K; Aryee C; Owiredu WK; Osei-Yeboah J; OwusuDabo E; and Laing EF (2015):

(Analysis of atherogenic and anthropometric profiles of normotensive and
Ghanaians in the Kumasi metropolis) British Journal of Medicine and Medical Research, vol. 7, no. 5, pp. 378-397.

Panagiotakos DB and Plychronopoulos E (2005):

The role of Mediterranean diet in the epidemiology of metabolic syndrome; converting epidemiology to clinical practice. Lipids Health Dis; 4: 7.

Puepet F; Uloko A; Akogu I and Aniekwensi E (2009):

"Prevalence of the metabolic syndrome among patients with type 2 diabetes mellitus in urban North-Central Nigeria," African Journal of Endocrinology and Metabolism, vol. 8, no. 1 .

Reitman $S$ and Frankel $S$ (1957):

"A colorimetric method for the determination of serum glutamic oxaloacetic and glutamic pyruvic transaminases". Am. J. Clin. Path. , 28: 56. 
Ruano Nieto CI; Melo Pérez JD; Mogrovejo Freire L; De Paula Morales KR and Espinoza Romero CV (2015):

(Prevalence of metabolic syndrome and associated risk factors in Ecuadorian university students). Nutr Hosp. $2015 \quad$ Apr 1;31(4):1574-81.

Sabir FM; Hassan DA and Elamin MI (2016):

Prevalence of metabolic syndrome among Young Sudanese University students using three different criteria of WHO, IDF and NCEP-ATPIII. Pediatr Neonatal Nurs; 2:2.

\section{Snedecor GW and Cochran WG} (1967):

Statistical Methods. 7th Ed., The Lowa State University Press., Ames, Lowa, U.S.A.

St-Onge MP (2005):

Relationship between body composition changes and changes in physical function and metabolic risk factors in aging. Curr.
Opin. Clin. Nutr. Metab. Care. 8:523-8.

Trinder $P$ and Ann S (1969):

"Enzymatic colorimetric test with lipid clearing factor to determine triglycerides". Clin.

Biochem. , $6: 24-27$.

Tompkins CL; Moran K; Preedom $S$ and Brock DW (2011):

Physical activity-induced improvements in markers of insulin resistance in overweight and obese children and adolescents. Curr Diabetes Rev. May;7(3): $\quad$ 164-170. Review.

Unadike B; Akpan N; Peters E; Essien I and Essien O (2009):

"Prevalence of the metabolic syndrome among patients with type 2 diabetes mellitus in Uyo, Nigeria," African Journal of Endocrinology and Metabolism, vol. 8, no. 1 .

Van Namen M; Prendergast L and Peiris C (2019): 
Supervised lifestyle intervention for people with metabolic syndrome improves outcomes and reduces individual risk factors of metabolic syndrome: $A$ systematic review and meta-analysis. / Metabolism Clinical and Experimental 101- 153988.

Walker S; Gurka M; Oliver M; Johns D and DeBoer (2012):

Racial / ethnic discrepancies in the metabolic syndrome begin in childhood and persist after adjustment for environmental factors. Nutr. Metab. Cardiovasc. Dis., 22: 141-148.

Young DS; Thomas DW; Friedman RB and Pestaner LC (1972).

Effects of drugs on clinical laboratory tests. Journal of Clinical Chemistry 18 (10):10411303

Table (1) Descriptive statistics of anthropometric data for the studied sample

\begin{tabular}{|l|l|}
\hline Anthropometric data & Mean \pm Std. Deviation \\
\hline Age $($ year $)$ & $\mathbf{3 9 . 3 6} \pm \mathbf{1 8 . 4 6}$ \\
\hline Weight $(\mathrm{kg})$ & $\mathbf{9 2 . 9 4} \pm \mathbf{1 6 . 0 0 0}$ \\
\hline Height $(\mathrm{cm})$ & $\mathbf{1 6 3 . 1 5} \pm \mathbf{7 . 6 7 6}$ \\
\hline BMI $\left(\mathrm{kg} / \mathrm{m}^{2}\right)$ & $\mathbf{3 3 . 5 9} \pm \mathbf{8 . 1 7 8}$ \\
\hline Waist circumference $(\mathrm{cm})$ & $\mathbf{1 0 2 . 2 1} \pm \mathbf{1 6 . 8 5 6}$ \\
\hline Hip circumference $(\mathrm{cm})$ & $\mathbf{1 1 1 . 5 5} \pm \mathbf{1 8 . 7 7 4}$ \\
\hline Waist to hip ratio & $\mathbf{0 0 . 9 2} \pm \mathbf{0 . 1 7 8}$ \\
\hline
\end{tabular}

Data expressed as Means $\pm S D(n=140)$. 
Table (2) Descriptive statistics for blood pressure and laboratory findings

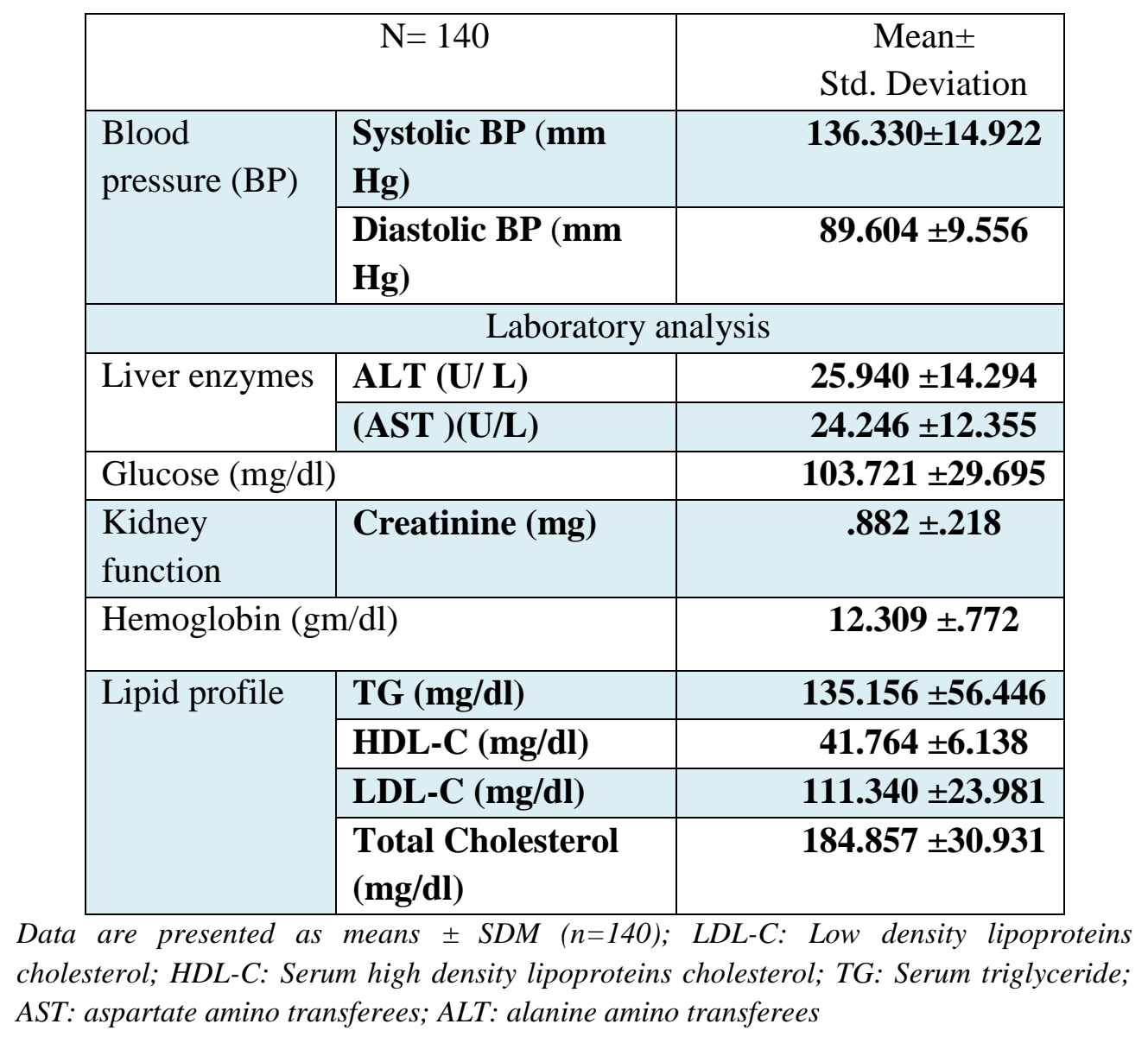


Table (3): Distribution of risk factors for metabolic syndrome diseases among study subjects

\begin{tabular}{|c|c|c|c|}
\hline \multicolumn{2}{|l|}{ Risk factor } & Frequency & Percent $\%$ \\
\hline \multicolumn{4}{|c|}{ Glucose } \\
\hline \multirow{2}{*}{$\begin{array}{l}\text { fasting blood sugar } \\
>100 \mathrm{mg} / \mathrm{dl}\end{array}$} & Yes & 77 & 55 \\
\hline & $\mathrm{No}$ & 63 & 45 \\
\hline \multicolumn{4}{|c|}{ Blood pressure } \\
\hline \multirow{2}{*}{$\begin{array}{l}\text { High blood pressure > } \\
\text { 130/85 mm Hg }\end{array}$} & Yes & 85 & 60.7 \\
\hline & No & 55 & 39.3 \\
\hline \multicolumn{4}{|c|}{ TG } \\
\hline \multirow{2}{*}{$\begin{array}{l}\text { High blood triglyceride } \\
>150 \mathrm{mg} / \mathrm{dl}\end{array}$} & Yes & 47 & 33.6 \\
\hline & No & 93 & 66.4 \\
\hline \multicolumn{4}{|c|}{ HDL } \\
\hline \multirow{2}{*}{$\begin{array}{l}\text { Low high density } \\
\text { lipoprotein }<40 \mathrm{Mg} / \mathrm{dl}\end{array}$} & Yes & 53 & 37.9 \\
\hline & No & 87 & 62.1 \\
\hline
\end{tabular}


Table (4): Distribution of dietary intake of energy, macronutrients and selected micronutrients for the studied sample compared to their RDA.

\begin{tabular}{|c|c|c|c|c|c|}
\hline \multicolumn{2}{|c|}{$\begin{array}{l}\text { Energy, Macronutrients \& } \\
\text { micronutrients }\end{array}$} & Male $\mathrm{N}=33$ & $\begin{array}{l}\text { Female } \\
\mathrm{N}=107\end{array}$ & $\begin{array}{l}\text { Total } \mathrm{N}= \\
140\end{array}$ & Sig \\
\hline \multirow[t]{3}{*}{ Kcal } & Low intake & $4(12.2 \%)$ & $25(23.3 \%)$ & $29(20.7 \%)$ & \multirow[t]{3}{*}{0.041} \\
\hline & $\begin{array}{l}\text { Normal } \\
\text { intake }\end{array}$ & $11(33.3 \%)$ & $22 \quad(20.6 \%)$ & $33(23.6 \%)$ & \\
\hline & High intake & $18(54.5 \%)$ & $\begin{array}{ll}60 & (56.1 \%)\end{array}$ & $78(55.7 \%)$ & \\
\hline \multirow[t]{3}{*}{ Carbohydrates } & Low intake & $5(15.2 \%)$ & 26 (24.3\%) & $31(22.1 \%)$ & \multirow[t]{3}{*}{0.112} \\
\hline & $\begin{array}{l}\text { Normal } \\
\text { intake }\end{array}$ & $7(21.2 \%)$ & $12(11.2 \%)$ & $19(13.6 \%)$ & \\
\hline & High intake & $21(63.6 \%)$ & $69(64.5 \%)$ & $90(64.3 \%)$ & \\
\hline \multirow[t]{3}{*}{ Protein } & Low intake & $6(18.2 \%)$ & $23(21.5 \%)$ & $29(20.7 \%)$ & \multirow[t]{3}{*}{0.231} \\
\hline & $\begin{array}{l}\text { Normal } \\
\text { intake }\end{array}$ & $11(33.3 \%)$ & $21(19.6 \%)$ & $32(22.9 \%)$ & \\
\hline & High intake & $16(48.5 \%)$ & $63(58.9 \%)$ & $79(56.4 \%)$ & \\
\hline \multirow[t]{3}{*}{ Fat } & Low intake & 7 (21.2\%) & $37(34.6 \%)$ & $44(31.4 \%)$ & \multirow[t]{3}{*}{0.878} \\
\hline & $\begin{array}{l}\text { Normal } \\
\text { intake }\end{array}$ & $8(24.2 \%)$ & $25(23.3 \%)$ & $33(23.6 \%)$ & \\
\hline & High intake & $18(54.5 \%)$ & $45(42.1 \%)$ & $63(45 \%)$ & \\
\hline \multirow[t]{3}{*}{ Fiber } & Low intake & $25(75.8 \%)$ & $77(72 \%)$ & $102(72.9 \%)$ & \multirow[t]{3}{*}{0.286} \\
\hline & $\begin{array}{l}\text { Normal } \\
\text { intake }\end{array}$ & 6 (18.2\%) & $17(15.9 \%)$ & $23(16.4 \%)$ & \\
\hline & High intake & $2(6 \%)$ & $13(12.1 \%)$ & $15(10.7 \%)$ & \\
\hline
\end{tabular}

* Percent of intake from RDA

$<75 \% \quad$ from RDA unacceptable level of consumption (low intake)

$>75-120 \%$ from RDA acceptable and adequate level of consumption (normal intake)

$>120 \%$ from RDA over consumption (High intake)

Adjusted from (DNPCNCD, 2008) 
Table (5): Comparing of pre and post intervention per sex and age according to anthropometric measurements for subsample.

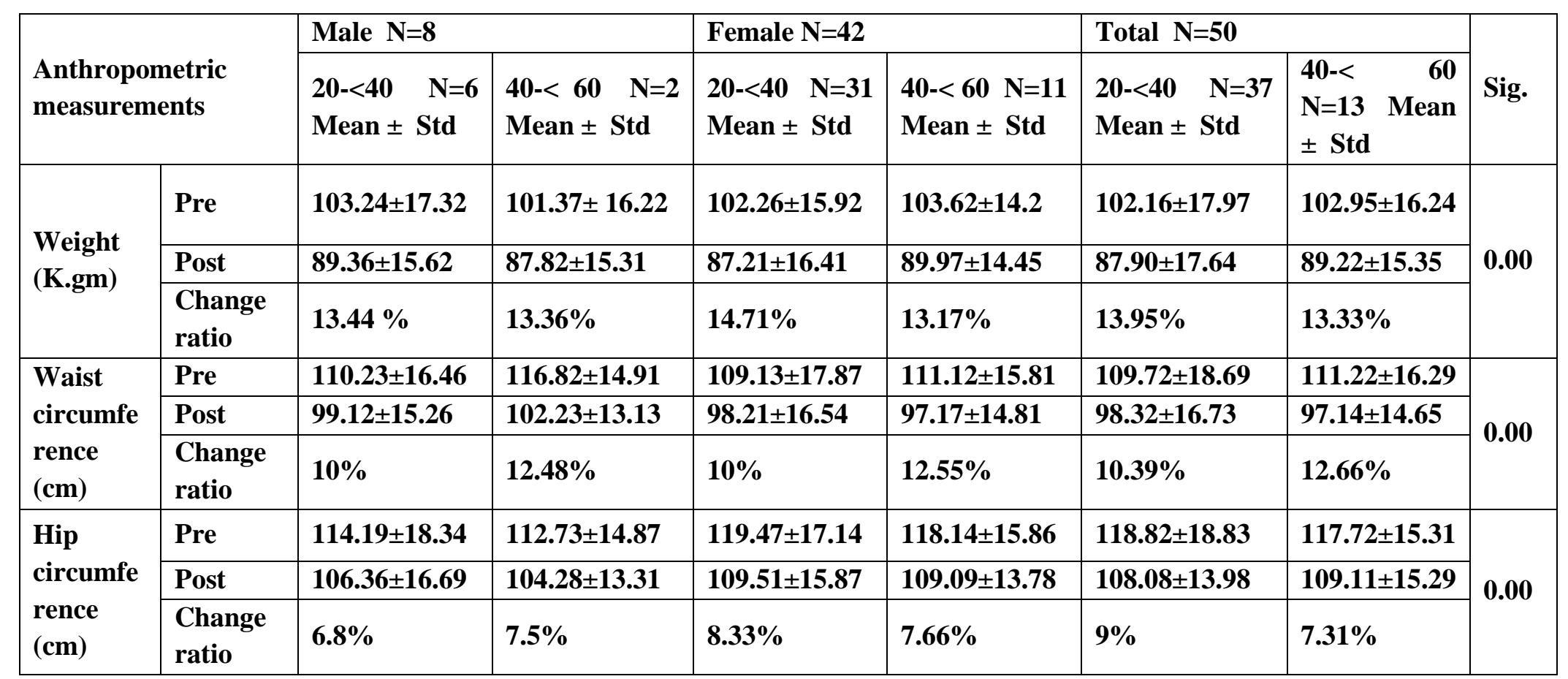


Table (6): Distribution of dietary intake of energy, macronutrients pre and post intervention compared to their RDA.

\begin{tabular}{|c|c|c|c|c|c|c|c|c|}
\hline \multicolumn{2}{|c|}{ Macronutrient } & \multicolumn{2}{|l|}{ Male N=8 (\%) } & \multicolumn{2}{|c|}{ Female $\mathrm{N}=42$} & \multicolumn{2}{|c|}{ Total $N=50$} & Sig \\
\hline Kcal & Low intake & $\begin{array}{l}\text { pre } \\
0(0 \%)\end{array}$ & $\begin{array}{l}\text { post } \\
0(0 \%)\end{array}$ & \begin{tabular}{|l|} 
Pre \\
$1(2.4 \%)$ \\
\end{tabular} & $\begin{array}{l}\text { post } \\
3(7.1 \%) \\
\end{array}$ & $\begin{array}{l}\text { pre } \\
(2 \%) \\
\end{array}$ & $\begin{array}{l}\text { post } \\
r(6 \%)\end{array}$ & \multirow{3}{*}{.000} \\
\hline & Normal intake & $3(37.5 \%)$ & $7(87.5 \%)$ & $15(35.7 \%)$ & $36(85.8 \%)$ & $1 \wedge(36 \%)$ & $\leqslant r(86 \%)$ & \\
\hline & High intake & $5(62.5 \%)$ & $1(12.5 \%)$ & $26(61.9 \%)$ & $3(7.1 \%)$ & $P^{\prime}(62 \%)$ & $\varepsilon(8 \%)$ & \\
\hline \multirow{3}{*}{$\begin{array}{l}\text { Carbohyd } \\
\text { rate }\end{array}$} & Low intake & $0(0 \%)$ & $1(12.5 \%)$ & $3(7.1 \%)$ & $2(4.8 \%)$ & $r(6 \%)$ & $r(6 \%)$ & \multirow[b]{3}{*}{.000} \\
\hline & Normal intake & $2(25 \%)$ & $6(75 \%)$ & $8 \quad(19.1 \%)$ & $36(85.7 \%)$ & $1 \cdot(20 \%)$ & $£ 2(84 \%)$ & \\
\hline & High intake & $6(75 \%)$ & $1(12.5 \%)$ & $31(73.8 \%)$ & $\begin{array}{ll}4 & (9.5 \%)\end{array}$ & $r v(74 \%)$ & $5(10 \%)$ & \\
\hline \multirow[t]{3}{*}{ Protein } & Low intake & $2(25 \%)$ & $1(12.5 \%)$ & $8(19.1 \%)$ & $5(11.9 \%)$ & $1 \cdot(20 \%)$ & $7(12 \%)$ & \multirow[b]{3}{*}{.000} \\
\hline & Normal intake & $3(37.5 \%)$ & $5(62.5 \%)$ & $14(33.3 \%)$ & $24(57.1 \%)$ & IV $(34 \%)$ & rq $(58 \%)$ & \\
\hline & High intake & $3(37.5 \%)$ & $2(25 \%)$ & $20(47.6 \%)$ & $13(31 \%)$ & $r r(46 \%)$ & $10(30 \%)$ & \\
\hline \multirow[t]{3}{*}{ Fat } & Low intake & $1(12.5 \%)$ & $2(25 \%)$ & $3(7.2 \%)$ & $9(21.4 \%)$ & $4(8 \%)$ & $11(22 \%)$ & \multirow[b]{3}{*}{.000} \\
\hline & Normal intake & $1(12.5 \%)$ & $4(50 \%)$ & $4(9.5 \%)$ & $30(71.4 \%)$ & $5(10 \%)$ & $34(68 \%)$ & \\
\hline & High intake & $6(75 \%)$ & $2(25 \%)$ & $35(83.3 \%)$ & $3(7.2 \%)$ & $41(82 \%)$ & $5(10 \%)$ & \\
\hline \multirow[t]{3}{*}{ Fiber } & Low intake & $5(62.5 \%)$ & $2(25 \%)$ & $26(61.9 \%)$ & $10(33.8 \%)$ & $31(62 \%)$ & $12(24 \%)$ & \multirow{3}{*}{.000} \\
\hline & Normal intake & $1(12.5 \%)$ & $3(37.5 \%)$ & $11(26.2 \%)$ & $21(50 \%)$ & $12(24 \%)$ & $24(48 \%)$ & \\
\hline & High intake & $2(25 \%)$ & $3(37.5 \%)$ & $5(11.9 \%)$ & $11(26.2 \%)$ & $7(14 \%)$ & $14(28 \%)$ & \\
\hline
\end{tabular}

* Percent of intake from RDA < $75 \%$ from RDA unacceptable level of consumption (low intake)

$\geq 75-120 \%$ from RDA acceptable and adequate level of consumption (normal intake) > $120 \% \quad$ from RDA over consumption (High intake) 
Table (7): Distribution of dietary intake of selected micronutrients for the studied sample pre and post intervention compared to their RDA.

\begin{tabular}{|c|c|c|c|c|c|c|c|c|}
\hline \multirow{2}{*}{\multicolumn{2}{|c|}{ Micronutrient }} & \multicolumn{2}{|c|}{ Male N=8 (\%) } & \multicolumn{2}{|c|}{ Female $\mathrm{N}=42$} & \multicolumn{2}{|c|}{ Total N= 50 } & \multirow[t]{2}{*}{ Sig } \\
\hline & & pre & Post & Pre & post & pre & post & \\
\hline \multirow[t]{3}{*}{ Iron } & Low intake & $3(37.5 \%)$ & $\mathbf{0}(\mathbf{0 \%})$ & $16(38.2 \%)$ & $3(7.2 \%)$ & $19(38 \%)$ & $3(6 \%)$ & \multirow{3}{*}{0.059} \\
\hline & Normal intake & $3(37.5 \%)$ & $5(62.5 \%)$ & $17(40.4 \%)$ & $25(59.5 \%)$ & $20(40 \%)$ & $30(60 \%)$ & \\
\hline & High intake & $2(25 \%)$ & $3(37.5 \%)$ & $9(21.4 \%)$ & $14(33.3 \%)$ & $11(7.9 \%)$ & $17(34 \%)$ & \\
\hline \multirow[t]{3}{*}{$\mathbf{C a}$} & Low intake & $4(50 \%)$ & $2(25 \%)$ & $22(52.4 \%)$ & $8(19.1 \%)$ & $26(52 \%)$ & $10(20 \%)$ & \multirow[b]{3}{*}{0.069} \\
\hline & Normal intake & $2(25 \%)$ & $5(62.5 \%)$ & $8(19.1 \%)$ & $30(71.4 \%)$ & $10(20 \%)$ & $35(70 \%)$ & \\
\hline & High intake & $2(25 \%)$ & $1(12.5 \%)$ & $12(28.5 \%)$ & $4(9.5 \%)$ & $14(28 \%)$ & $5(10 \%)$ & \\
\hline \multirow[t]{3}{*}{$\mathbf{N a}$} & Low intake & 0 (0\%) & $3(37.5 \%)$ & $2(4.8 \%)$ & $6(14.3 \%)$ & $2(4 \%)$ & $9(18 \%)$ & \multirow[b]{3}{*}{0.042} \\
\hline & Normal intake & $1(12.5 \%)$ & $4(50 \%)$ & $4(9.5 \%)$ & 31(73.8) & $5(10 \%)$ & $35(70 \%)$ & \\
\hline & High intake & $7(87.5 \%)$ & $1(12.5 \%)$ & $36(85.7 \%)$ & $5(11.9 \%)$ & $43(86 \%)$ & $6(12 \%)$ & \\
\hline \multirow[t]{3}{*}{$\mathbf{K}$} & Low intake & $1(12.5 \%)$ & $0(0 \%)$ & $13(31 \%)$ & $\mathbf{0}(\mathbf{0 \%})$ & $14(28 \%)$ & $\mathbf{0}(0 \%)$ & \multirow[b]{3}{*}{0.067} \\
\hline & Normal intake & $4(50 \%)$ & $6(75 \%)$ & $24(57.1 \%)$ & $40(95.2 \%)$ & $28(56 \%)$ & $46(92 \%)$ & \\
\hline & High intake & $3(37.5 \%)$ & $2(25 \%)$ & $5(11.9 \%)$ & $2(4.8 \%)$ & $8(16 \%)$ & $4(8 \%)$ & \\
\hline
\end{tabular}

* Percent of intake from RDA

$<75 \%$ from RDA unacceptable level of consumption (low intake)

$\geq 75-120 \%$ from RDA acceptable and adequate level of consumption (normal intake)

$>120 \%$ from RDA over consumption (High intake) 
Ekbal M Mohamed, El Sayed M Hammad, Safaa T Gohari and Manar M Abd Elrhman

Table (8): Comparison of laboratory findings for sub-sample pre and post intervention.

\begin{tabular}{|c|c|c|c|c|}
\hline \multicolumn{3}{|c|}{ Laboratory analysis } & Mean \pm S.D $N=50$ & Sig \\
\hline \multirow{2}{*}{\multicolumn{2}{|c|}{$\begin{array}{l}\text { Glucose } \\
\text { (mg/ dI) }\end{array}$}} & Pre & $114.30 \pm 34.25$ & \multirow{2}{*}{0.00} \\
\hline & & Post & $103.18 \pm 22.11$ & \\
\hline \multirow{8}{*}{ Lipid profile } & \multirow{2}{*}{$\begin{array}{c}\text { T.G } \\
(\mathrm{mg} / \mathrm{dI})\end{array}$} & Pre & $150.63 \pm 79.88$ & \multirow{2}{*}{0.00} \\
\hline & & Post & $132.22 \pm 61.68$ & \\
\hline & \multirow{2}{*}{$\begin{array}{c}\text { LDL-c } \\
(\mathrm{mg} / \mathrm{dI})\end{array}$} & Pre & $127.16 \pm 26.73$ & \multirow{2}{*}{0.00} \\
\hline & & Post & $110.52 \pm 22.31$ & \\
\hline & \multirow{2}{*}{$\begin{array}{c}\text { HDL-c } \\
(\mathrm{mg} / \mathrm{dI})\end{array}$} & Pre & $40.02 \pm 7.34$ & \multirow{2}{*}{0.00} \\
\hline & & Post & $46.63 \pm 6.43$ & \\
\hline & \multirow{2}{*}{$\begin{array}{c}\text { Cholesterol } \\
\text { (mg/ dI) }\end{array}$} & Pre & $203.41 \pm 28.86$ & \multirow{2}{*}{0.00} \\
\hline & & Post & $185.33 \pm 22.01$ & \\
\hline \multirow{4}{*}{ Liver enzymes } & \multirow{2}{*}{$\begin{array}{l}\text { ALT } \\
\mathbf{U} / \mathbf{L}\end{array}$} & Pre & $28.51 \pm 10.16$ & \multirow{2}{*}{0.00} \\
\hline & & Post & $26.96 \pm 7.96$ & \\
\hline & \multirow{2}{*}{$\begin{array}{l}\text { AST } \\
\text { U/L }\end{array}$} & Pre & $21.05 \pm 8.68$ & \multirow{2}{*}{0.00} \\
\hline & & Post & $19.10 \pm 5.39$ & \\
\hline \multirow{2}{*}{ Kidney function } & \multirow{2}{*}{$\begin{array}{c}\text { Creatinine } \\
(\mathrm{mg} / \mathrm{dl})\end{array}$} & Pre & $0.87 \pm 0.18$ & \multirow{2}{*}{0.00} \\
\hline & & Post & $0.85 \pm 0.15$ & \\
\hline \multirow{2}{*}{\multicolumn{2}{|c|}{ Hemoglobin (gm/dl) }} & Pre & $11.91 \pm 0.87$ & \multirow{2}{*}{0.00} \\
\hline & & Post & $12.41 \pm 0.53$ & \\
\hline
\end{tabular}

Data are presented as means $\pm S D M(n=50)$;

LDL-C: Low density lipoproteins cholesterol; HDL-C: Serum high density lipoproteins cholesterol; TC: Serum total cholesterol; TG: Serum triglyceride; AST: aspartate amino transferees; ALT: alanine amino transferees 


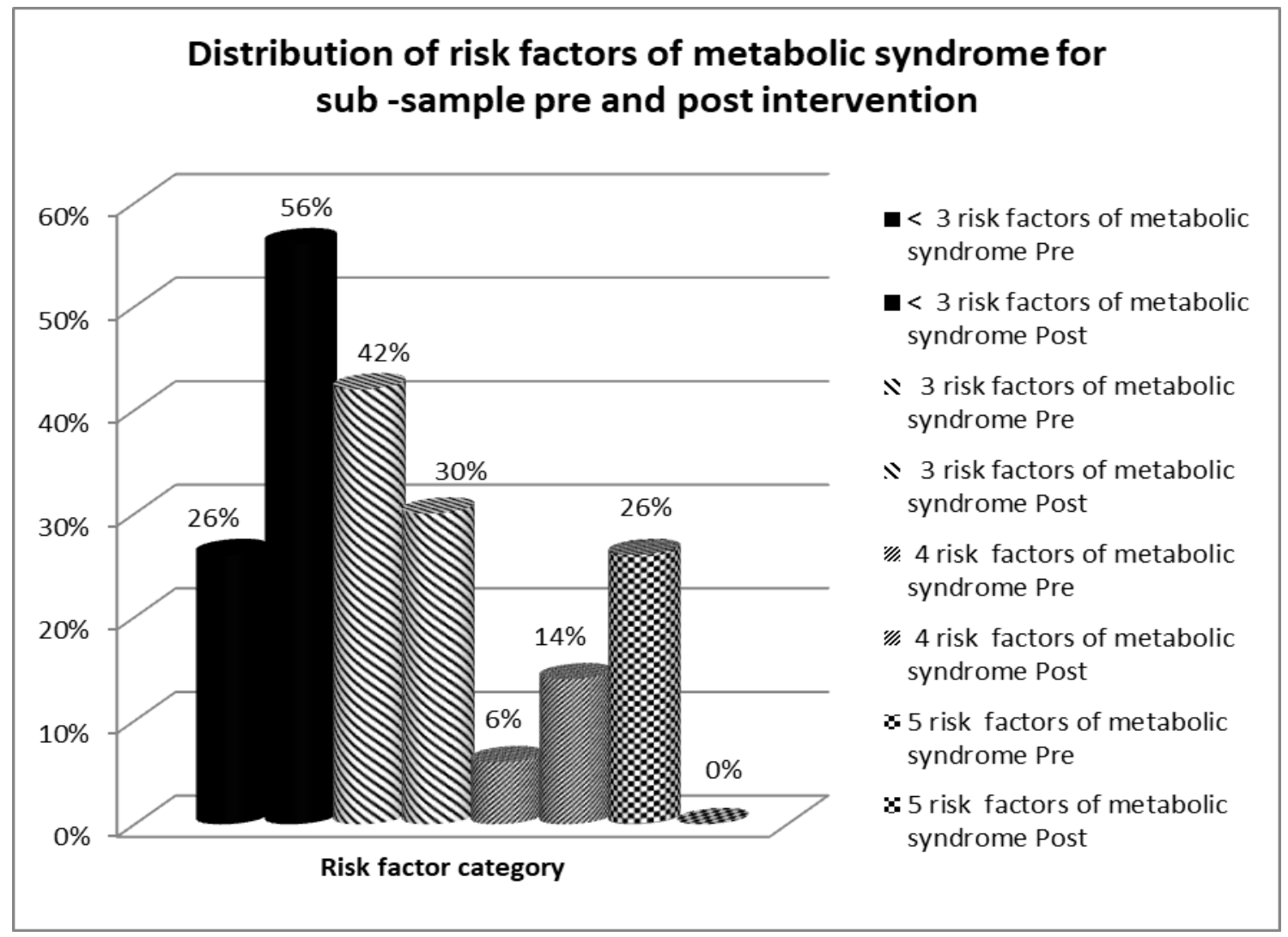

Figure (1): Distribution of risk factors of metabolic syndrome for sub -sample pre and post intervention 


\section{تأثثير التدخل التغذوي على بعض عوامل الخطورة الخاصة بالمتلازمة الايضية بين البالغين}

إقبال محمود محمد' السيد محمود حماد` صفاء طلعت جوهري' منار مصطفي عبد الرحمن؟.

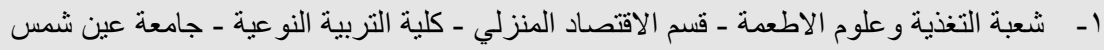
r- إ - قسم التغذية الاكلينيكية ـالمعهد القومي للتغذية ـ القاهرة.

المتلازمة الايضية هي مجموعة من عو امل الخطورة تحدث معظمها في وقت واحد مثل السمنة

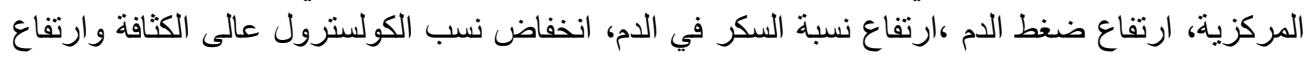

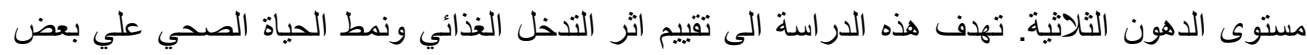

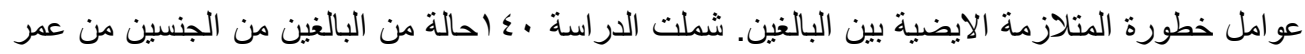

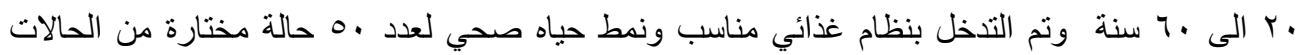

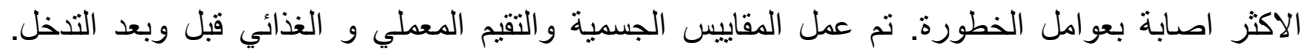

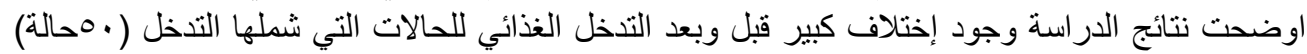

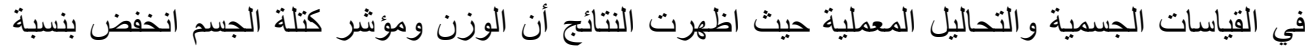

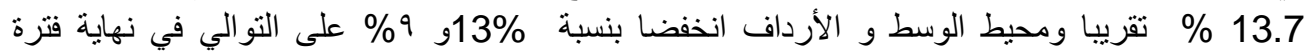

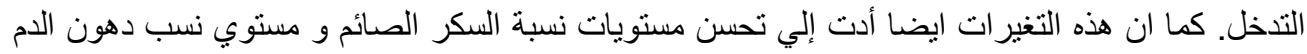

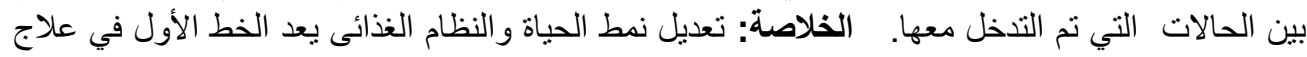

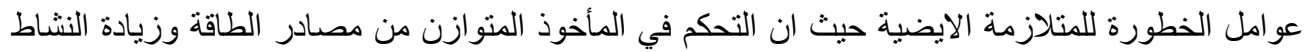

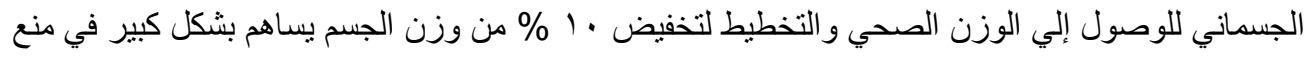

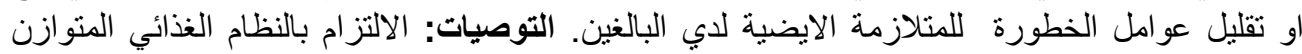

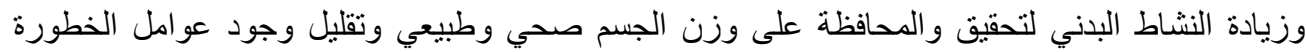
الخاصة بالمتلازمة الايضية بين البالغين.

الكلمات الدالة : المتلازمة الايضية ـ عوامل الخطورةـ البالغين ـ التذخل التغذوي 